\title{
Secondary metabolites profiling of Vernonia amygdalina Del. in response to copper-induced abiotic stress
}

\begin{tabular}{|c|c|}
\hline $\begin{array}{l}\text { Authors: } \\
\text { Abosede Adu } \\
\text { Anthony Ojek } \\
\text { Bamidele Johr } \\
\text { Opeyemi N. A }\end{array}$ & 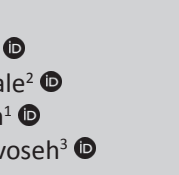 \\
\hline $\begin{array}{l}\text { Affiliations: } \\
\text { Department } \\
\text { Faculty of Scie } \\
\text { State Universi }\end{array}$ & $\begin{array}{l}\text { f Botany, } \\
\text { nces, Lagos } \\
\text { ty, Ojo, Nigeria }\end{array}$ \\
\hline $\begin{array}{l}\text { Department } \\
\text { Faculty of Scie } \\
\text { State Universi }\end{array}$ & $\begin{array}{l}\text { f Biochemistry, } \\
\text { nces, Lagos } \\
\text { ty, Ojo, Nigeria }\end{array}$ \\
\hline $\begin{array}{l}{ }^{3} \text { Department o } \\
\text { Faculty of Com } \\
\text { and Applied Sc } \\
\text { University of T } \\
\text { Vanderbijlpark }\end{array}$ & $\begin{array}{l}\text { f Chemistry, } \\
\text { aputer Science } \\
\text { cience, Vaal } \\
\text { echnology, } \\
\text {, South Africa }\end{array}$ \\
\hline $\begin{array}{l}\text { Corresponding } \\
\text { Abosede Adu, } \\
\text { adu_bose@ya }\end{array}$ & $\begin{array}{l}\text { g author: } \\
\text { hoo.co.uk }\end{array}$ \\
\hline $\begin{array}{l}\text { Dates: } \\
\text { Received: } 17 \mathrm{~N} \\
\text { Accepted: } 14 \text { L } \\
\text { Published: } 17\end{array}$ & $\begin{array}{l}\text { May } 2020 \\
\text { Jec. } 2020 \\
\text { Feb. } 2021\end{array}$ \\
\hline $\begin{array}{l}\text { How to cite th } \\
\text { Adu, A., Ojeka } \\
\text { \& Avoseh, O.N } \\
\text { 'Secondary me } \\
\text { profiling of Vel } \\
\text { amygdalina De } \\
\text { to copper-indu } \\
\text { stress', Journal } \\
\text { Plants for Econ } \\
\text { Development } \\
\text { https://doi.org } \\
\text { jomped.v5i1.9 }\end{array}$ & $\begin{array}{l}\text { is article: } \\
\text { le, A., John, B. } \\
\text { l., 2021, } \\
\text { tabolites } \\
\text { rnonia } \\
\text { el. in response } \\
\text { ced abiotic } \\
\text { l of Medicinal } \\
\text { omic } \\
5(1) \text {, a91. } \\
\text { /10.4102/ } \\
1\end{array}$ \\
\hline $\begin{array}{l}\text { Copyright: } \\
\text { (c) 2021. The A } \\
\text { Licensee: AOSI } \\
\text { is licensed und } \\
\text { Creative Comm } \\
\text { Attribution Lice }\end{array}$ & $\begin{array}{l}\text { Uthors. } \\
\text { IS. This work } \\
\text { ler the } \\
\text { nons } \\
\text { ense. }\end{array}$ \\
\hline Read online: & \\
\hline 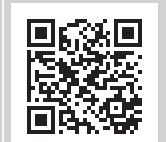 & $\begin{array}{l}\text { Scan this QR } \\
\text { code with your } \\
\text { smart phone or } \\
\text { mobile device } \\
\text { to read online. }\end{array}$ \\
\hline
\end{tabular}

Background: Vernonia amygdalina is a green leafy vegetable that grows in tropical Africa and popularly cultivated in the southern part of Nigeria for its economic, nutritional and ethnomedicine value.

Aims: This study analysed the influence of copper-induced abiotic stress on the deoxyribonucleic acid and secondary metabolites of $V$. amygdalina.

Setting: Analyses of plant material were carried out in the Department of Botany, Lagos State University.

Methods: Deoxyribonucleic acid (DNA) extraction and Inter Simple Sequence Repeat (ISSR) amplification were performed. Copper $(\mathrm{Cu})$ concentration in leaves and stem of $V$. amygdalina was determined using inductively coupled plasma-optical emission spectroscopy (ICP-OES), secondary metabolites were determined using gas chromatography-mass spectrometry (GCMS) and the effect on DNA amplification and profiling was analysed using gel electrophoresis.

Results: After 41 days of cultivation, the stem of $V$. amygdalina significantly bioaccumulated $37 \mathrm{mg} / \mathrm{L}, 50 \mathrm{mg} / \mathrm{L}$ and $215 \mathrm{mg} / \mathrm{L}$ of Cu after spiking with $400 \mathrm{mg} / \mathrm{L}, 1000 \mathrm{mg} / \mathrm{L}$ and $2000 \mathrm{mg} / \mathrm{L}$, respectively, whilst the leaves accumulated $52 \mathrm{mg} / \mathrm{L}, 100 \mathrm{mg} / \mathrm{L}$ and $350 \mathrm{mg} / \mathrm{L}$ of Cu, respectively. Copper-impregnated soil influenced phytochemicals of the plants by causing inconsistent increase and decrease in specific compounds such as levomenthol, methyl stearate and glycerine. Deoxyribonucleic acid bands of the stem and leaf of $V$. amygdalina from control site showed no band shift, whilst band shift occurred in the stem and leaf of the Cu-spiked V. amygdalina.

Conclusion: This study revealed the leaves of $V$. amygdalina having higher $\mathrm{Cu}$ accumulation capacity than the stems. Also, $\mathrm{Cu}$ alters the quality and quantity of phytochemicals in plant parts.

keywords: V. amygdalina; copper; phytochemicals; abiotic stress; bioaccumulation.

\section{Introduction}

Vernonia amygdalina, commonly called 'bitter leaf', is a member of the daisy family. It is a shrub that may grow to a height of $2.5 \mathrm{~m}$ when matured and bears small white flowers that form small fruits with little nuts inside. The plants usually domicile in the forest zone, woodlands and open grassland in the wild or cultivated (Akachukwu 2001). It is indigenous to tropical Africa (Kokwaro 2009) and propagated by seeds and stems cuttings, which grow faster than seedlings. It is cultivated as food and medicines amongst the local people of Nigeria (Ewuro in Yoruba, Chusardoki in Hausa \& Onugbu) and Cameroon (Lusoga) (Constance et al. 2020). It grows very well under full sunlight and humid environmental conditions. Goats feed on the leaves, dry stem provides fuel, young twigs serve as toothpicks, or chewing sticks and the branches are used as stakes to line fields (Burkill 1995). Phytochemicals reported in the plants includes alkaloids, saponins, terpenes, coumarins, flavonoids, phenolic acids, lignans, Xanthones and anthraquinones and steroids (Ijeh \& Ejike 2011). The production of phytochemical is affected by factors such as nature and type of soil, climatic conditions, type, plant parts, the plant's geographical location, age of the plant and its biosynthetic pathways.

In recent years, there has been an increasing ecological and global public health concern associated with environmental contamination of heavy metals (Tchounwou et al. 2012). Heavy metals such as mercury $(\mathrm{Hg})$, lead $(\mathrm{Pb})$ and calcium $(\mathrm{Ca})$ have no severe or beneficial effect on the plants. Still, their accumulation over time in mammals' bodies that consume them may cause serious illness 
(Kabata-Pendias \& Pendias 2001). Copper (Cu) is one of the micronutrients needed in minimal quantities by plants. The acceptable range, according to the World Health Organization (WHO 2005) in the growing medium is 0.05 ppm - 0.5 ppm, while in most tissues the range is between $3 \mathrm{ppm}$ and $10 \mathrm{ppm}$. $\mathrm{Cu}$ metal rarely caused high-toxicity effect and its deficiency is barely reported; hence, it is best to avoid either extreme as both can affect crop growth and quality (Mccauley 2011).

Reports have shown that abiotic environmental stress such as salinity, low and elevated temperatures, drought, alkalinity and increased metal concentrations are potentially harmful to plants and its phytochemicals (Christie, Alfenito \& Walbot 1994). For instance, nutrient stress has a marked effect on phenolic levels in plant tissues, as reported by Bryant, Chapin and Klein (1983). The concentration of heavy metals in soil seldom reaches a level sufficient to cause an osmotic disturbance in plants, through the downward sipping into the root. Decreased elongation of the primary roots, impaired accordance growth, increased root dieback or reduced root hair caused by toxic ions all exert a deleterious effect on the root absorbing area and water uptake (Dhawale 2013).

Sequel to the above background, this study aimed to evaluate the influence of $\mathrm{Cu}$-induced abiotic stress on the DNA and secondary metabolites of $V$. amygdalina.

\section{Materials and methods Experimental site}

The research project was carried out in the botanical greenhouse garden of the Department of Botany, Lagos State University (GPS location of $6^{\circ} 27^{\prime} 57.8^{\prime \prime} \mathrm{N}, 3^{\circ} 12^{\prime} 00.4^{\prime \prime} \mathrm{E}$, Ojo) between April and May 2018. The stem of V.amygdalina used was collected from a cultivated farm on 17 April 2018 at Ijanikin, Otto/Awori LCDA, Lagos state. Four specimens of $V$. amygdalina were taken to the Lagos State University (LSH) Herbarium for identification and authentication. The plant materials were identified, and the following voucher numbers, LSH20/0016, LSH20/0017, LSH20/0018 and LSH20/0019, were issued as sample markers for ease of reference. The loamy soil used for the experiment was collected at the vegetable farm, Lagos State University main gate, Ojo, on 18 April 2018.

\section{Planting procedure and spiking}

Ten previously perforated, pre-washed plastic buckets were used. Copper sulphate $\left(\mathrm{CuSO}_{4}\right)$ of $400 \mathrm{mg} / \mathrm{L}, 1000 \mathrm{mg} / \mathrm{L}$ and $2000 \mathrm{mg} / \mathrm{L}$ were prepared using standard procedure. In brief, $400 \mathrm{mg}, 1000 \mathrm{mg}$ and $2000 \mathrm{mg}$ of $\mathrm{CuSO}_{4}$ anhydrous were dissolved in $1 \mathrm{~L}$ of distilled water to make the respective concentrations and standardised using the titrimetric method (Danny 2020). Each plastic bucket was preloaded with $500 \mathrm{~g}$ of soil previously spiked with varying copper sulphate concentrations except the control sample that was unspiked with $\mathrm{Cu}$ solution. The stem of $V$. amygdalina was cut into 10 pieces, each $6 \mathrm{~cm}$ long, and was planted in the already spiked soil samples to a depth of about $16 \mathrm{~cm}$. Distilled water was used to wet the plant for 3 days, according to Burkill methodology. The plant was allowed to germinate for about 14 days.

\section{Analysis of soil, leaves and stems of Vernonia amygdalina}

Laboratory analysis of the unspiked soil sample and fresh $V$. amygdalina stem was first carried out before planting to determine the initial composition of $\mathrm{Cu}$ before subjecting them to spiking. After 41 days of planting, following spiking, $\mathrm{Cu}$ analysis of the soil and $V$. amygdalina stem and leaves was carried out to ascertain the influence of absorption of materials by the plant on the translocation of the copper in $V$. amygdalina (Towolawi et al. 2017).

\section{Preparation of samples}

All the apparatus used in the analysis were immersed in $10 \%$ of nitric acid $\left(\mathrm{HNO}_{3}\right)$ and left for a day. The apparatus was taken out and washed with distilled water (Talbot \& Weiss 1994). The plants were divided into two parts, that is, the stem and the leaves, to determine the parts of $V$. amygdalina plants that accumulate more heavy metals. The different parts (stems and leaves) were pulverised in a blender to increase the surface area and dried at a temperature of $65^{\circ} \mathrm{C}$ for $24 \mathrm{~h}$ in an oven.

\section{Plant digestion for metal analysis}

The dried plant samples, $10 \mathrm{~g}$, were sieved and measured appropriately by using the analytical balance. The sample was transferred into a $50 \mathrm{~mL}$ conical flask, and $10 \mathrm{~mL}$ of $65 \%$ $\mathrm{HNO}_{3}$ was poured into the conical flask, heated for $2 \mathrm{~h}$ at $140{ }^{\circ} \mathrm{C}$ until a clear solution was achieved. The solution was concentrated to the $5 \mathrm{~mL}$, allowed to cool and filtered using Whatman filter paper $125 \mathrm{~mm}$ mesh size. The solution was made up to the $50 \mathrm{~mL}$ with distilled water and kept in a 120 $\mathrm{mL}$ plastic container, stored in a refrigerator until analysis by inductively coupled plasma-optical emission spectroscopy (ICP-OES) (Talbot \& Weiss 1994), which was analysed in triplicates.

\section{Gas chromatography-mass spectrometry analysis}

To analyse the effect of different concentrations of $\mathrm{Cu}$ on the secondary metabolites, gas chromatography-mass spectrometry (GC-MS) was used. Gas chromatography-mass spectrometry was programmed as follows: injector port temperature was set to $250{ }^{\circ} \mathrm{C}$, interface temperature set as $250{ }^{\circ} \mathrm{C}$ and source kept at $200{ }^{\circ} \mathrm{C}$. The oven temperature programmed as a variable $\left(70{ }^{\circ} \mathrm{C}\right.$ for $2 \mathrm{~min}, 150^{\circ} \mathrm{C}$ at $8^{\circ} \mathrm{C} / \mathrm{min}$, up to $260{ }^{\circ} \mathrm{C}$ at $10{ }^{\circ} \mathrm{C} / \mathrm{min}$ ), split ratio set as $1: 50$ and the injector used was the splitless mode. The DB - 5 MS Nonpolar column $(0.25 \mathrm{~mm}$ OD $\times 0.25 \mu \mathrm{m}$ ID $\times 30 \mathrm{~m}$ length $)$ procured from Agilent Co., United States, was used. Helium was used as the carrier gas at $1 \mathrm{~mL} / \mathrm{min}$. The MS was set to scan from $50 \mathrm{Da}$ to $650 \mathrm{Da}$. The source was maintained at $200^{\circ} \mathrm{C}$ and $<40$ motor vacuum pressure. The ionisation energy was $70 \mathrm{eV}$. The MS 
contains an inbuilt pre-filter, which reduced the neutral particles. The data system has two inbuilt libraries for searching and matching the spectrum. NIST4 and WILEY9 each contain more than 5 million references. Only those compounds with spectral fit values equal to or greater than 700 were considered positive identification (Martinez et al. 2004).

\section{Deoxyribonucleic acid extraction}

Hundred milligram of the fresh plant of V. amygdalina (stem and leaves) was weighed and rinsed with distilled water and blended in a mortal with $200 \mu \mathrm{L}$ phosphate buffer saline (PBS). The mixture was later transferred to a $1.5 \mathrm{~mL}$ tube and centrifuged at high speed for 3 min to collect pellets in line with the protocol (Gumińska et al. 2018). The DNA was obtained and sent for the ISSR amplification of DNA and gel electrophoresis to compare the DNA bands of both the control and the spiked sample.

\section{Ethical consideration}

This article followed all ethical standards for research without direct contact with human or animal subjects.

\section{Results}

\section{Copper concentration in the soil and Vernonia amygdalina's stem and leaves}

\section{Unspiked plant and soil (Control)}

The concentration of $\mathrm{Cu}$ in soil and stem bark samples showed a relatively small amount. The soil and the stem of $V$. amygdalina samples used for the experiment revealed that the soil sample contained $5.00 \mathrm{mg} / \mathrm{L}$, whilst the stem had $2.20 \mathrm{mg} / \mathrm{L}$.

Copper content after spiking: Table 1 shows $\mathrm{Cu}$ absorption levels by the soil, stem bark and the leaf after 41 days of $V$. amygdalina cultivation. The leaf sample absorbed an average of $251 \mathrm{mg} / \mathrm{L}$ of $\mathrm{Cu}$ for the three spiked categories of concentrations, after 41 days of cultivation. Whilst the stem had $100 \mathrm{mg} / \mathrm{L}$, soil had an average of $1308 \mathrm{mg} / \mathrm{L}$ for

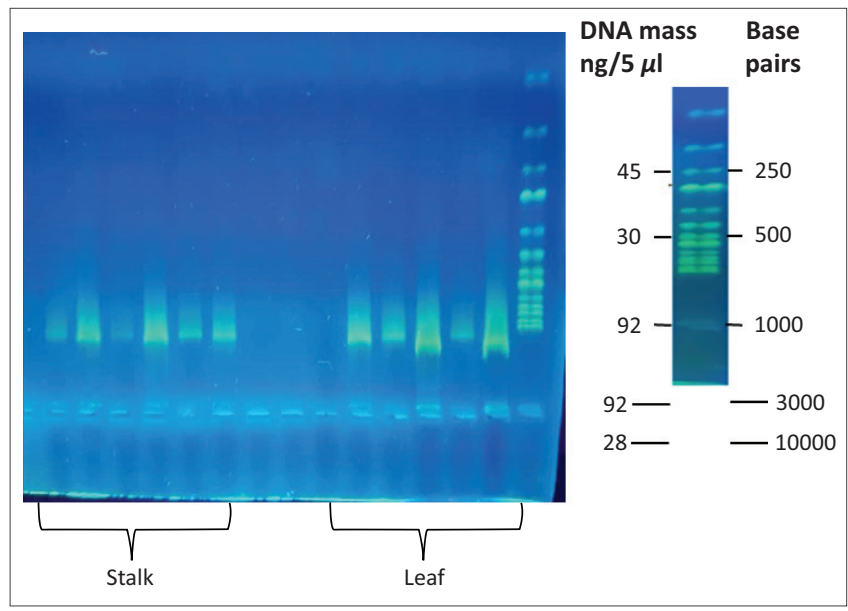

FIGURE 1: Plate 1 showing the deoxyribonucleic acid bands of Vernonia amygdalina of control experiment. the three spiked categories of concentrations. There was increase in concentration of the extracts as the concentration of the spiked $\mathrm{Cu}$ solution increased. The result showed that the leaf sample accumulated more $\mathrm{Cu}$ than the stem bark. In addition to the metal uptake by the plant, it was observed that there was poor root development and the leaves showed yellowish coloration and poor branch development.

The secondary metabolites in the spiked and unspiked stem and leaves of $V$. amygdalina analysed by GC-MS are shown in Table 2. Compounds were arranged according to their occurrence in different concentrations of preloaded $\mathrm{Cu}$ metal. Several changes occur between the constituents of leaf and stem, changes in concentration and crude extracts of plants. On the other hand, Table 3 shows the summary of the major components and their occurrences. 9-Octadecenoic acid, methyl ester, (Z)-hexadecanoic acid, methyl ester, glycerine, levomenthol, methyl stearate, $\mathrm{N}$, N-dimethylaminoethanol, oxime-, methoxy-phenyl- and Silanediol, dimethyl- occurred in at least two of the extracts. Glycerine and levomenthol were more predominant in the leaves samples: $7.14 \%$ and $73.83 \%$ in the $400 \mathrm{mg} / \mathrm{L} \mathrm{Cu}$ and unspiked samples, respectively. Methyl stearate was also present in the unspiked samples of the leaves (29.90\%) and stem $(25.40 \%)$, but with inconsistent presence in the $\mathrm{Cu}$ laden extracts.

Deoxyribonucleic acid profiling of Vernonia amygdalina: Deoxyribonucleic acid bands of the stem and leaf of $V$. amygdalina from control site showed no band shift, while band shift occurred in the stem and leaf of the $\mathrm{Cu}$ spiked V. amygdalina (Figures 1 and 2).

TABLE 1: Level of Copper in the soil, stem and leaves of Vernonia amygdalina after 41 days of planting.

\begin{tabular}{lccc}
\hline $\begin{array}{l}\text { Spiked in soil } \\
\text { samples (mg/L) }\end{array}$ & $\begin{array}{c}\text { Soil after planting } \\
\text { for } \mathbf{4 1} \text { days }(\mathbf{m g} / \mathrm{L})\end{array}$ & $\begin{array}{c}\text { Stem after planting } \\
\text { for } \mathbf{4 1} \text { days }(\mathbf{m g} / \mathrm{L})\end{array}$ & $\begin{array}{c}\text { Leaf after planting } \\
\text { for } \mathbf{4 1} \text { days }(\mathbf{m g} / \mathrm{L})\end{array}$ \\
\hline 400 & $395.12 \pm 1.22$ & $37.00 \pm 0.47$ & $52.00 \pm 2.47$ \\
1000 & $1180.00 \pm 0.12$ & $50.00 \pm 0.24$ & $100.00 \pm 1.62$ \\
2000 & $2350.03 \pm 0.04$ & $215.03 \pm 0.35$ & $350.00 \pm 0.31$ \\
Control & $5.00 \pm 0.12$ & $4.00 \pm 1.25$ & $5.00 \pm 1.81$ \\
\hline
\end{tabular}

Note: Results represent SEM \pm S.D from $n=3$.

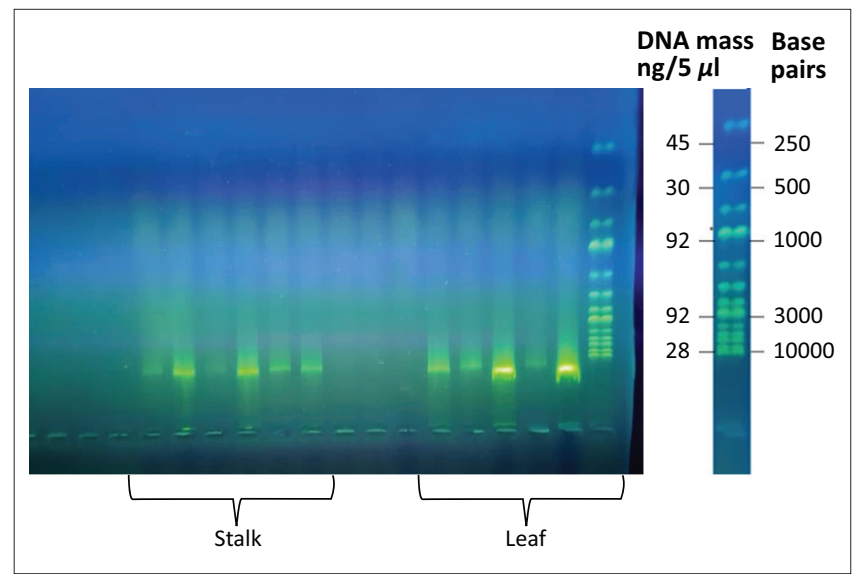

FIGURE 2: Plate 2 showing the deoxyribonucleic acid bands of Vernonia amygdalina with heavy metal (Copper) concentration. 
TABLE 2: Gas chromatography-mass spectrometry constituent of unspiked and spiked stem of Vernonia amygdalina at different concentrations.

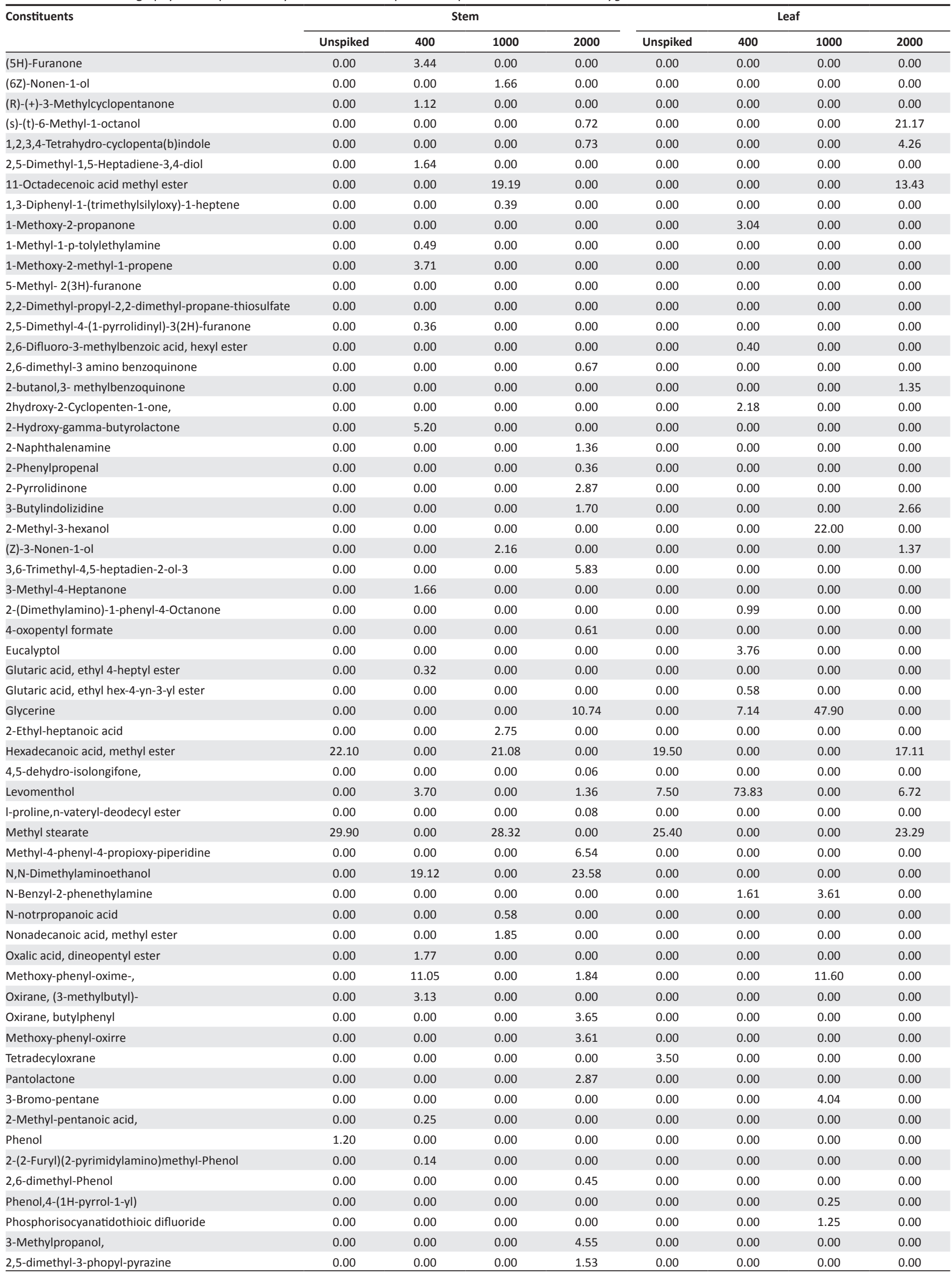


TABLE 2 (Continues...): Gas chromatography-mass spectrometry constituent of unspiked and spiked stem of Vernonia amygdalina at different concentrations.

\begin{tabular}{|c|c|c|c|c|c|c|c|c|}
\hline \multirow[t]{2}{*}{ Constituents } & \multicolumn{4}{|c|}{ Stem } & \multicolumn{4}{|c|}{ Leaf } \\
\hline & Unspiked & 400 & 1000 & 2000 & Unspiked & 400 & 1000 & 2000 \\
\hline 1,2,3,6-tetrahydro-1-methyl-4-phenol pyridine & 0.00 & 0.00 & 0.00 & 11.30 & 0.00 & 0.00 & 0.00 & 0.00 \\
\hline 2-methyl-5-phenyl-pyrrole, & 0.00 & 0.42 & 0.00 & 0.00 & 0.00 & 0.00 & 0.00 & 0.00 \\
\hline R(-)3,7-dimethyl-1,6-Octadiene & 0.00 & 0.00 & 0.00 & 0.00 & 0.00 & 0.00 & 0.00 & 0.67 \\
\hline RS-2,3-hexanediol & 0.00 & 0.00 & 0.00 & 0.00 & 0.00 & 0.00 & 1.55 & 0.00 \\
\hline dimethyl-Silanediol & 0.00 & 28.60 & 0.00 & 7.50 & 0.00 & 0.00 & 0.00 & 0.00 \\
\hline Tetradecanoic acid, 12-methyl-,methyl ester $\mathrm{E}$ & 2.10 & 0.00 & 0.00 & 0.00 & 0.00 & 0.00 & 0.00 & 0.00 \\
\hline Tetradecanoic acid, 12-methyl-,methyl ester S & 0.00 & 0.00 & 1.43 & 0.00 & 0.00 & 0.00 & 0.00 & 0.00 \\
\hline Tetradecanoic acid, 12-methyl-,methyl esterate & 0.00 & 0.00 & 0.00 & 0.00 & 0.00 & 0.00 & 0.00 & 1.80 \\
\hline Tetradecyne & 0.00 & 0.00 & 0.00 & 0.00 & 5.50 & 0.00 & 0.00 & 0.00 \\
\hline Total & 86.6 & 100.00 & 100.00 & 100.00 & 100.00 & 100.00 & 100.00 & 100.00 \\
\hline
\end{tabular}

TABLE 3: Overall constituents of compounds in spiked and unspiked stem and leaves of Vernonia amygdalina.

\begin{tabular}{|c|c|c|c|c|c|c|c|c|}
\hline \multirow[t]{2}{*}{ Constituents } & \multicolumn{4}{|c|}{ Stem } & \multicolumn{4}{|c|}{ Leaves } \\
\hline & Unspiked & 400 & 1000 & 2000 & Unspiked & 400 & 1000 & 2000 \\
\hline 6-octadecanoic acid, methyl ester & 0.00 & 0.00 & 0.00 & 0.00 & 0.00 & 0.00 & 0.00 & 21.17 \\
\hline 11-octadecenoic acid methyl ester & 0.00 & 0.00 & 19.19 & 0.00 & 0.00 & 0.00 & 0.00 & 0.00 \\
\hline 9,12-Octadecanoic acid, methyl ester & 0.00 & 0.00 & 0.00 & 0.00 & 0.00 & 0.00 & 0.00 & 13.43 \\
\hline 9-Octadecenoic acid, methyl ester, (Z)- & 18.70 & 0.00 & 0.00 & 0.00 & 6.30 & 0.00 & 0.00 & 0.00 \\
\hline $\begin{array}{l}\text { Diethylamine, N-(diisopropylphosphino) } \\
\text { methyl- }\end{array}$ & 0.00 & 0.00 & 0.00 & 0.00 & 0.00 & 0.00 & 22.00 & 0.00 \\
\hline Glycerine & 0.00 & 0.00 & 0.00 & 10.74 & 0.00 & 7.14 & 47.90 & 0.00 \\
\hline Hexadecanoic acid, methyl ester & 22.10 & 0.00 & 21.08 & 0.00 & 19.50 & 0.00 & 0.00 & 17.11 \\
\hline Levomenthol & 0.00 & 3.70 & 0.00 & 1.36 & 7.50 & 73.83 & 0.00 & 6.72 \\
\hline Methyl stearate & 29.90 & 0.00 & 28.32 & 0.00 & 25.40 & 0.00 & 0.00 & 23.29 \\
\hline $\mathrm{N}, \mathrm{N}$-Dimethylaminoethanol & 0.00 & 19.12 & 0.00 & 23.58 & 0.00 & 0.00 & 0.00 & 0.00 \\
\hline Oxime-, methoxy-phenyl-_ & 0.00 & 11.05 & 0.00 & 1.84 & 0.00 & 0.00 & 11.60 & 0.00 \\
\hline Silanediol, dimethyl- & 0.00 & 28.60 & 0.00 & 7.50 & 0.00 & 0.00 & 0.00 & 0.00 \\
\hline
\end{tabular}

\section{Discussions}

Plants are complex organisms because of numerous cells that they contain. In approximation, a single Arabidopsis plant could have approximately 100 million cells per gram fresh weight (Gibeaut et al. 1997). Because of such complexity, several parameters affect the growth and development of plants. Amongst these parameters, environmental, proteomics and metabolomics affect the yield of plant products by as much as $70 \%$ (Boyer 1982).

In this study, the concentration of $\mathrm{Cu}$ for the soil $(5 \mathrm{mg} / \mathrm{L})$ and $V$. amygdalina $(2.20 \mathrm{mg} / \mathrm{L})$ in the control site was within the World Health Organization (WHO) permissive levels of between $10 \mathrm{mg} / \mathrm{kg}$ and $30 \mathrm{mg} / \mathrm{kg}$ in medicinal plants and soil, respectively (WHO 1996, 2005). Therefore, there will be proper growth and development of the plants and such plants cannot pose any danger for human and other animals that may feed on them. However, the negative effects of spiking the soil with graded higher levels of $\mathrm{Cu}$ concentration far above the permissive level were obvious in plants growth and development. Akachuku (Akachukwu 2001) had reported that land use for food production can be contaminated with heavy metals, including $\mathrm{Cu}$ from natural and anthropogenic sources such as water smelt, irrigation with waste, disposal of solid waste, vehicle exhaust and adjacent industrial activities. In this study, bioaccumulation of $\mathrm{Cu}$ by the leaf and stem of $V$. amygdalina showed that it is a good research material for phytoremediation. The concentration of $\mathrm{Cu}$ being higher in leaves compared to the concentration found in the stem may be as a result of higher translocation rate in the leaf parts compared to the stem (Quartacci, Cosi \& Navari-Izzo 2001). Reports have shown that heavy metals are toxic because they tend to bioaccumulate in plants and animals, bioconcentrate in the food chain and attack specific organs in the body.

The influence of heavy metals on phytochemicals has been reported. The finding of Prasad et al. (2011), which analysed the effect of heavy metals on the essential oil yield of sweet basil (Ocimum basilicum L.) revealed that increase in $\mathrm{Cu}, \mathrm{Cd}, \mathrm{Mo}$ and $\mathrm{Zn}$ concentrations decreases the linalool and increases 1-8 cineole content in the essential oil of sweet basil.

In the present study, several changes in the concentration of $\mathrm{Cu}$ resulted in the preponderance of masking of some phytochemicals. In the leaf sample, levomenthol yield was $73.83 \%$ at $400 \mathrm{mg} / \mathrm{L}$ of $\mathrm{Cu}$ concentration, Glycerine (47.90\%) at $1000 \mathrm{mg} / \mathrm{L}$ and methyl stearate $(23.29 \%)$ at $2000 \mathrm{mg} / \mathrm{L}$ to mention a few. These compounds and others identified in the analysis are growth regulators of plants during stress and have been figured in the control of $V$. amygdalina growth and development as observed in the research. It is therefore not 
surprising how the plant was able to survive the presence of high concentration of $\mathrm{Cu}$ in its environment. The fact that all the experimental plants did not contain the same concentration might be as a result of their different morphological features and physiological composition. The mechanisms by which the various constituents in the $V$. amygdalina were increased or decreased by the application of $\mathrm{Cu}$ metals could be related to the uptake of essential and nonessential or phytotoxic metals as opined by Prasad et al. (2011). In addition, several enzymatic activities are usually responsible for the interconversion of acetyl-Co A to several phytochemicals such as terpenoids, alkaloids, flavonoids and phenolic compounds. Hence, changes in phytochemicals observed in this study could be alluded to biotransformation of the enzymatic pathway by the presence of heavy metals, inhibition of enzymes, inactivation of biomolecules and oxidative stress (Fryzova et al. 2017).

In this study, the DNA bands of stem and leaves of V. amygdalina in the control experiment, which displayed no band shift, indicated healthy growth and development in the plants (Nicolia et al. 2013). In the Cu-spiked experiment, as the concentration of heavy metals increased (400 ppm, 1000 ppm and $2000 \mathrm{ppm}$ ), the bands of the DNA reduced, both in the stem and the leaves, and this indicated that the DNA of the $V$. amygdalina stalk and leaves was being affected by the concentration of the heavy metal $(\mathrm{Cu})$. This could be as a result of the fact that copper bonds to the DNA or the plant molecule, thereby preventing the formation of chromosomes, and may inhibit DNA synthesis and hinder cell division (Prasad \& Strzalka 1999). Quartacci et al. (2001) also reported that plants grown in the presence of high levels of copper normally show reduced biomass and chlorotic symptoms. This is in line with this study at the collection of plants for laboratory test.

\section{Conclusion}

The results of this study represent an obvious role of $\mathrm{Cu}$ in the alteration of the DNA and secondary metabolites in $V$. amygdalina. The deposit of the Cu metal increases as the spiked concentrations increased, with the leaf sample accumulating more of the metals. The effect on phytochemicals is revealed in quantity and quality of the phytochemicals present before and after spiking. In addition, the reduction in the DNA bands also shows the negative impact of $\mathrm{Cu}$ at elevated concentrations. However, the mechanism of translocation and hormonal changes in this plant are still subjected to further studies.

\section{Acknowledgements \\ Competing interests}

The authors have declared that no competing interests exist.

\section{Authors' contributions}

A.A. conceptualised the idea, designed the project and corrected the manuscript; B.J. performed the experiment and prepared manuscript; O.N.A. interpreted data, corrected manuscript and supervised the research; A.O. supervised the student, interpreted data and corrected manuscript.

\section{Funding information}

This research received no specific grant from any funding agency in the public, commercial or not-for-profit sectors.

\section{Data availability statement}

Experimental data are available for future referencing from the corresponding author.

\section{Disclaimer}

The views and opinions expressed in this article are those of the author(s) and do not necessarily reflect the official policy or position of any affiliated agency of the authors.

\section{References}

Akachukwu, C.O., 2001, 'Growth of bitter leaf (Vernonia amygdalina) and nutritive values of its processed and unprocessed leaves', Discovery \& Innovation 13(3\&4), 227-232. https://doi.org/10.4314/dai.v13i3.15616

Boyer, J.S., 1982, 'Plant productivity and environment', Science 218(4571), 443-448. https://doi.org/10.1126/science.218.4571.443

Bryant, J.P., Chapin, F.S.I. \& Klein, D.R., 1983, 'Carbon/nutrient balance of boreal plants in relation to vertebrate herbivory', Oikos 40(3), 357-368. https://doi. org/10.2307/3544308

Burkill, M.H., 1995, The useful plants of tropical Africa, families J-L. (Royal Bota), Royal Botanic Gardens Kew, Richmond.

Christie, P.J., Alfenito, M.R. \& Walbot, V., 1994, 'Impact of low-temperature stress on general phenylpropanoid and anthocyanin pathways: Enhancement of transcript abundance and anthocyanin pigmentation in maize seedlings', Planta 194, 541-549. https://doi.org/10.1007/BF00714468

Constance, N., Joy, D.N., Nkeiruka, O.A., Ahamefula, E., Chidimma, A. \& Oluchi, A.A., 2020, 'Protective effects of bi-herbal formulation of aqueous extracts of Vernonia amygdalina and gongronema latifolium against gentamicin induced nephrotoxicity and liver injury in rats', Asian Journal of Research in Biochemistry 7(4), 12-20. https://doi.org/10.9734/ajrb/2020/v7i430144

Danny, E., 2020, Standardization of acid and base solutions, viewed 12 December 2020, from http://www.chem.latech.edu/ deddy/chem104/104Standard.html.

Dhawale, P.G., 2013, 'Phytochemical analysis of some medicinal plants from yanatmal district (Ms) India', The International Journal of Engineering and Science 2(1), 65-66.

Fryzova, R., Pohanka, M., Martinkova, P., Cihlarova, H., Brtnicky, M. \& Hladky, J. et al., 2017, 'Oxidative stress and heavy metals in plants', Reviews of Environmental Contamination and Toxicology245,129-156. https://doi.org/10.1007/398_2017_7

Gibeaut, D.M., Hulett, J., Cramer, G.R. \& Seemann, J.R., 1997, 'Maximal biomass of arabidopsis thaliana using a simple, low-maintenance hydroponic method and favorable environmental conditions', Plant Physiology 115, 317-319. https://doi. org/10.1104/pp.115.2.317

Gumińska, N., Płecha, M., Walkiewicz, H., Hałakuc, P., Zakryś, B. \& Milanowski, R., 2018, 'Culture purification and DNA extraction procedures suitable for nextgeneration sequencing of euglenids', Journal of Applied Phycology 30(6), 3541-3549. https://doi.org/10.1007/s10811-018-1496-0

Ijeh, I.I. \& Ejike, C.E.C.C., 2011, 'Current perspectives on the medicinal potentials of Vernonia amygdalina Del.', Journal of Medicinal Plants Research 5(7), 1051-1061.

Kabata-Pendias, A. \& Pendias, H., 2001, Trace metals in soils and plants, 2nd edn., CRC Press, Boca Raton, FL.

Kokwaro, J.O., 2009, Medicinal plants of East Africa, health and fitness, University of Nairobi press, Nairobi.

Martinez, M.J., Roy, S., Archuletta, A.B., Wentzell, P.D., Anna-Arriola, S.S. \& Rodriguez, A.L. et al., 2004, 'Genomic analysis of stationary-phase and exit in saccharomyces cerevisiae: Gene expression and identification of novel essential genes', Molecular Biology of the Cell 15(12), 5295-5305. https://doi.org/10.1091/mbc.e03-11-0856

Mccauley, A., 2011, 'Plant nutrient functions and deficiency and toxicity symptoms visual symptoms as a diagnostic tool', vol. 9, pp. 1-16, Montana State University Extension, viewed 12 December 2020, from http://mtvernon.wsu.edu/wp-content/ uploads/2016/01/Plant-Nutrient-Functions-and-Deficiency-and-ToxicitySymptoms-MSU-2013.pdf. 
Nicolia, A., Manzo, A., Veronesi, F. \& Rosellini, D., 2013, 'An overview of the last 10 years of genetically modified engineered crop safety research', Critical Reviews in Biotechnology 34(1), 77-88. https://doi.org/10.3109/07388551.20 13.823595

Prasad, A., Kumar, S., Khaliq, A. \& Pandey, A., 2011, 'Heavy metals and arbuscular mycorrhizal (AM) fungi can alter the yield and chemical composition of volatile oi of sweet basil (Ocimum basilicum L.)', Biology and Fertility of Soils 47(8), a853. https://doi.org/10.1007/s00374-011-0590-0

Prasad, M.N.V. \& Strzalka, K., 1999, 'Impact of heavy metal on photosynthesis', in M.N.V. Prasad \& J. Hagemeyer (eds.), Heavy metal stress in plants, vol. 17 pp. 117-138, Springer Publishers, Berlin.

Quartacci, M.F., Cosi, E. \& Navari-Izzo, F., 2001, ‘Lipid and NADPH-dependent superoxide production in plasma membrane vesicles from roots of wheat grown under copper deficiency or excess', Journal of Experimental Botany 52, 77-84. https://doi.org/10.1093/jxb/52.354.77
Talbot, J. \& Weiss, A., 1994, Laboratory methods for ICP-MS analysis of trace metals in precipitation, Hazardous Materials Lab, Champaign, IL.

Tchounwou, P.B., Yedjou, C.G., Patlolla, A.K. \& Sutton, D.J., 2012, 'Molecular, clinical and environmental toxicicology Volume 3: Environmental toxicology', Molecular, Clinical and Environmental Toxicology 101, 133-164. https://doi.org/10.1007/9783-7643-8340-4_6

Towolawi, A.T., Arowolo, T.A., Bada, B.S., Badejo, A.A. \& Taiwo, A.M., 2017 'Phytoextraction assessment of green amaranth (Amaranthus viridis Linn.) grown on soil amended with sewage sludge', Ife Journal of Science 19(1), a133. https://doi. org/10.4314/ijs.v19i1.13

World Health Organization (WHO), 1996, Permissible limits of heavy metals in soil and plants, World Health Organization, Geneva.

World Health Organization (WHO), 2005, Quality control methods for medicinal plant, materials, World Health Organization, Geneva. 